\title{
Variability of 3 cytoplasmically encoded proteins in the Triticum genus
}

\author{
N. Bahrman, \\ M.-L. Cardin, \\ M. Seguin, \\ M. Zivy and \\ H. Thiellement
}

\author{
Laboratoire de Génétique des Systèmes Végétaux, \\ INRA-CNRS-UPS, La Ferme du Moulon, \\ 91190 Gif-sur-Yvette, France.
}

The comparison of two-dimensional protein patterns from wheat alloplasmic lines (etiolated seedling stage) has allowed us to define three variable polypeptides with a cytoplasmic determination: the large subunit of ribulose bisphosphate carboxylase/oxygenase and two other polypeptides that are likely to be two forms of the chloroplastic beta subunit of ATP synthase. Two cytoplasmic types are found among the Triticum species. Of the diploids studied only $T$. speltoides and $T$. aucheri had these same cytoplasmic markers as $T$. aestivum. $T$. turgidum and $T$. timopheevi.

\section{INTRODUCTION}

Many experiments have been done to study the cytoplasmic diversity in Triticum species (including the formerly called Aegilops species). Morphological and physiological studies on wheat alloplasmic lines (Kihara, 1951; Fukasawa, 1953; Hori and Tsunewaki, 1967; Maan and Lucken, 1970; Tsunewaki et al., 1974; Kofoid and Maan, 1982) have led to the classification of 75 accessions (33 species) into 12 plasma types (Tsunewaki, 1980).

The large subunit (LS) of ribulose bisphosphate carboxylase/oxygenase (Rubisco) has been used as a cytoplasmic marker. In the main study by Hirai and Tsunewaki (1981) two types were found among 39 Triticum cytoplasms. More recently, molecular data obtained by restriction fragment length polymorphism of organellar DNAs have revealed a great diversity, from which phylogenetic relationships have been deduced (Vedel et al., 1978; Ogihara and Tsunewaki, 1982; Bowman et al., 1983; Tsunewaki and Ogihara, 1983).

However the donor of the cytoplasm and B genome of the tetraploid Triticum turgidum (AABB) and hexaploid T. aestivum (AABBDD) cultivated wheats is still a subject of active controversy. Depending upon their experimental approaches, authors have proposed $T$. bicorne (Sears, 1956), T. speltoïdes (Sarkar and Stebbins,

Reprint requests to Dr H. Thiellement.
1956; Riley et al., 1958), T. searsii (Feldman and Kislev, 1977), T. sharonense (Kushnir and Halloran, 1981), all from the Sitopsis section, or T. urartu (Johnson, 1972).

On the other hand $T$. speltoides (Maan and Lucken, 1971) and T. aucheri (Tsunewaki, 1980), also from the Sitopsis section, have been suggested as the origin of the cytoplasm and $\mathrm{G}$ genome of the timopheevi group (AAGG, AAAAGG).

On the basis of the restriction patterns of chloroplast DNA (cpDNA) of alloplasmic Chinese Spring (CS) lines, Tsunewaki and Ogihara (1983) have proposed that an ancestor of $T$. longissima was the B genome donor and an ancestor of $T$. aucheri was the $G$ genome donor.

The comparison of the proteins of wheat alloplasmic lines by high resolution two dimensional (2D) gel electrophoresis has led to the detection of variability in 3 cytoplasmically-encoded polypeptides (Bahrman and Thiellement, 1987). In this paper the variability observed for these 3 polypeptides in 50 Triticum genotypes is reported, with special emphasis on the Sitopsis section.

\section{MATERIAL AND METHODS}

\section{Plant material}

The various lines and accessions used in this study are listed in table 1. The alloplasmic lines of Chinese Spring (CS) were obtained from Prof. K. Tsunewaki (Kyoto, Japan) and the alloplasmic 
Table 1 List of the plant material used and their 2D cytoplasmic type

\begin{tabular}{|c|c|c|}
\hline $\begin{array}{l}\text { Nuclear and cytoplasmic } \\
\text { genomes }\end{array}$ & Plasmatype* & $\begin{array}{l}\text { 2D cytoplasmic } \\
\text { type }\end{array}$ \\
\hline Chinese Spring/tauschii $\dagger$ & $\mathrm{D}$ & $\mathrm{LS} 2, \mathrm{C} 3, \mathrm{C} 4$ \\
\hline Selkirk/ ventricosum $\dagger$ & $\mathrm{D}$ & $\mathrm{LS} 2, \mathrm{C} 3, \mathrm{C} 4$ \\
\hline Selkirk/ cyclindricum $\dagger$ & $\mathrm{D}$ & $\mathrm{LS} 2, \mathrm{C} 3, \mathrm{C} 4$ \\
\hline T. tauschii var. typicum & $\mathrm{D}$ & $\mathrm{LS} 2, \mathrm{C} 3, \mathrm{C} 4$ \\
\hline T. tauschii var. meyere & $\mathrm{D}$ & LS2, C3, C4 \\
\hline $\begin{array}{l}\text { T. tauschii var. } \\
\text { Strangulatum }\end{array}$ & $\mathrm{D}$ & $\mathrm{LS} 2, \mathrm{C} 3, \mathrm{C} 4$ \\
\hline Selkirk/juvenale $\dagger$ & $\mathrm{D}^{2}$ & $\mathrm{LS} 2, \mathrm{C} 3, \mathrm{C} 4$ \\
\hline Selkirk/ovatum $\dagger$ & $\mathbf{M}^{0}$ & $\mathrm{LS} 2, \mathrm{C} 3, \mathrm{C} 4$ \\
\hline Selkirk/muticum $\dagger$ & $\mathrm{M}^{\mathrm{t}}$ & $\mathrm{LS} 2, \mathrm{C} 3, \mathrm{C} 4$ \\
\hline $\begin{array}{l}\text { T. monococcum var. } \\
\text { monococcum }\end{array}$ & $\mathrm{A}$ & LS2, C3, C4 \\
\hline $\begin{array}{l}\text { T. monococcum var. } \\
\text { boeoticum }\end{array}$ & A & $\mathrm{LS} 2, \mathrm{C} 3, \mathrm{C} 4$ \\
\hline T. urartu (5 accessions) & A & LS2, C3, C4 \\
\hline Selkirk/bicorne $\dagger$ & $\mathrm{S}^{\mathrm{b}}$ & $\mathrm{LS} 2, \mathrm{C} 3, \mathrm{C} 4$ \\
\hline Selkirk/kostchii $\dagger$ & $\mathrm{S}^{v}$ & $\mathrm{LS} 2, \mathrm{C} 3, \mathrm{C} 4$ \\
\hline Selkirk/variabile $\dagger$ & $S^{v}$ & $\mathrm{LS} 2, \mathrm{C} 3, \mathrm{C} 4$ \\
\hline T. bicorne ( 3 accessions) & $\mathrm{S}^{\mathrm{b}}$ & $\mathrm{LS} 2, \mathrm{C} 3, \mathrm{C} 4$ \\
\hline $\begin{array}{l}\text { T. sharonense } \\
\text { (3 accessions) }\end{array}$ & $S^{1}$ & $\mathrm{LS} 2, \mathrm{C} 3, \mathrm{C} 4$ \\
\hline$T$. searsii ( 2 accessions) & $\mathrm{S}^{\mathrm{b}, \mathrm{v}}$ & $\mathrm{LS} 2, \mathrm{C} 3, \mathrm{C} 4$ \\
\hline $\begin{array}{l}\text { T. longissima } \\
\text { (4 accessions) }\end{array}$ & $\mathrm{S}^{1,2}$ or $\mathrm{S}$ & $\mathrm{LS} 2, \mathrm{C} 3, \mathrm{C} 4$ \\
\hline $\begin{array}{l}\text { T. speltoïdes var. typicum } \\
\text { (2 accessions) }\end{array}$ & $\mathrm{S}$ or $\mathrm{G}$ & LS1, C1, C2 \\
\hline $\begin{array}{l}\text { T. speltoïdes var. } \\
\text { polyatherum }\end{array}$ & $\mathrm{S}$ or $\mathrm{G}$ & LS1, C1, C2 \\
\hline $\begin{array}{l}\text { T. speltoïdes var. } \\
\text { compactum }\end{array}$ & $\mathrm{S}$ or $\mathrm{G}$ & LS1, C1, C2 \\
\hline T. aucheri & $\mathrm{G}$ & LS1, C1, C2 \\
\hline Selkirk/timopheevi† & G & $\mathrm{LS} 1, \mathrm{C} 1, \mathrm{C} 2$ \\
\hline $\begin{array}{l}\text { Chinese Spring/turgidum } \\
\text { var. dicoccoides } \dagger\end{array}$ & $\mathrm{S}$ & LS1, C1, C2 \\
\hline $\begin{array}{l}\text { T. turgidum var. dicoccum } \\
\text { dicoccum }\end{array}$ & $\mathrm{S}$ & LS1, C1, C2 \\
\hline T. turgidum var. durum & $\mathrm{S}$ & LS1, C1, C2 \\
\hline $\begin{array}{l}\text { T. turgidum var. } \\
\text { diccoccoides }\end{array}$ & $\mathrm{S}$ & LS1, C1, C2 \\
\hline $\begin{array}{l}\text { T. turgidum var. } \\
\text { carthlicum }\end{array}$ & $\mathrm{S}$ & LS1, C1, C2 \\
\hline $\begin{array}{l}\text { T. aestivum var. aestivum } \\
\text { (8 lines) }\end{array}$ & $\mathrm{S}$ & LS1, C1, C2 \\
\hline
\end{tabular}

* According to Tsunewaki 1980.

+ Alloplasmic line.

Selkirk lines from Prof. S. S. Maan (Fargo, North Dakota, U.S.A.), the Triticum turgidum, T. tauschii and $T$. monococcum accessions were furnished by Dr Y. Cauderon (INRA Versailles, France) and Dr G. Doussinault (INRA le Rheu, France). The species of the Sitopsis section are represented by accessions obtained from Japan (Germ Plasm Institute of Kyoto), the United States (Prof. E. R. Sears, Columbia, Missouri) and France (INRA Le Rheu).

\section{Protein extraction and electrophoresis}

The proteins of 7-day-old dark germinated seedlings were extracted as previously described (Damerval et al. 1986) and the electrophoresis performed by two different methods: in $16 \times 16 \mathrm{~cm}$ slab gels as described by Colas des Francs and Thiellement (1985) and in $20 \times 24 \mathrm{~cm}$ slab gels as in Bahrman and Thiellement (1987). The analysis focuses on variation in 3 polypeptides easy to recognise using these two types of electrophoresis. In addition, data obtained in previous experiments (Zivy et al., 1983, 1984) were included in the analysis.

\section{RESULTS}

As shown in fig. 1, six spots vary (presence/absence) according to the cytoplasm. Their behaviour suggests that they correspond to 3 pairs of cytoplasmic alleles: for each polypeptide the two allelic forms differ in isoelectric point and slightly in relative molecular mass. The LS1 and LS2 polypeptides are the two forms of the LS of Rubisco as demonstrated previously (Zivy et al., 1984).

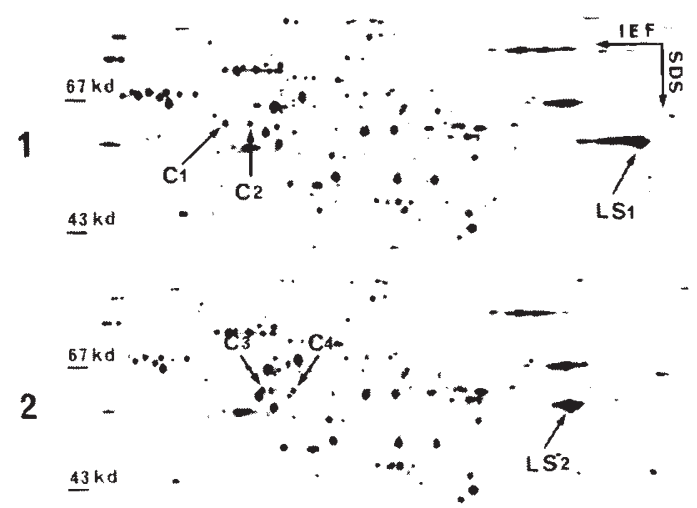

Figure 1 Sections of 2D gels of proteins obtained from alloplasmic Chinese Spring lines with $T$. turgidum (1) and $T$. tauschii (2) cytoplasms. Proteins with cytoplasmically determined variability are indicated. On the left the relative molecular mass of the proteins are given in kilodaltons.

The other polypeptides $\mathrm{C} 1 / \mathrm{C} 3$ and $\mathrm{C} 2 / \mathrm{C} 4$ are located in a chloroplastic membrane as shown by subcellular fractionation (Granier et al., 1986). The two polypeptides found in one cytoplasm show the same pattern of partial enzymatic proteolysis (data not shown). The shift of the two protein spots on the gels from one to the other cytoplasmic type is exactly parallel. Thus it is tempting to 
speculate that these two proteins are two products of the same gene. This may occur if one or both gene products undergo a post-translational modification such as phosphorylation or glycosylation which are known to induce changes in isoelectric point and even in relative molecular mass (Anderson and Anderson, 1979; Zannis and Breslow, 1981). These two proteins are cytoplasmically-encoded, as shown by comparing alloplasmic lines (table 1). Their isoelectric points, between $p \mathrm{H} 5$ and 6 , and their relative molecular mass, heavier than the LS one, circa 56-58 kilodaltons (see fig. 1), are in the range of the electrophoretic properties described for the beta subunit of the coupling factor CF1 of the chloroplastic ATP synthase complex, located in the chloroplastic membrane (Ellis, 1981; Howe et al., 1982; Rémy and Ambard-Bretteville, 1983). It is thus hypothesised that $\mathrm{C} 1 / \mathrm{C} 2$ and $\mathrm{C} 3 / \mathrm{C} 4$ are two products of the atp $B$ gene, which is located on the chloroplastic DNA (Howe et al., 1982). These two spots have been described as cytoplasmic variants in previous reports from our laboratory with the spot numbers 1304 to 1307 (Zivy et al., 1984). This clear and reproducible variation was considered partly as quantitative since the polypeptides were not completely separated with the method used at that time.

The observations for these 6 spots on the plant material examined are listed in table 1 . Only 2 groups of cytoplasms can be discriminated using this criterion. One group consists of the representatives of the A, M and D genomes and many of the species from the Sitopsis section. $\dot{T}$. aestivum, $T$. turgidum, T. timopheevi and only 2 diploid species, $T$. speltoides and T. aucheri, are found in the other group.

\section{DISCUSSION}

The results presented here are in accordance with the extensive study on alloplasmic CS lines by Hirai and Tsunewaki (1981) on the variation of the LS, except for T. longissima. The T. longissima LS was found by the Japanese workers to be identical to the T. aestivum LS. But, according to the data here reported (table 1), the T. longissima LS is different from the T. aestivum LS in the four accessions analyzed. As Tsunewaki and Ogihara (1983) found no difference between the cpDNA of these same two alloplasmic lines, they concluded that $T$. longissima was the cytoplasmic donor of $T$. aestivum, However in no other comparison between cpDNA of closely related species did they find such identity. This fact, in addition with the results reported above raises questions about the peculiar nature of the CS/longissima alloplasmic line used by Tsunewaki and his coworkers.

In every case examined the more acidic form of the LS of Rubisco is found associated with the more basic forms of $C$ (table 1). Thus the appearance of mutated forms of the LS and C polypeptides must have occurred either simultaneously or in a relatively short period of time. In this connection, following the hypothesis that the $\mathrm{C}$ proteins are two forms of the beta subunit of ATP synthase, it is very remarkable that the two chloroplastic genes involved, $r b c L$ and $a t p B$, are very close to each other on the wheat cpDNA (Howe et al., 1982).

The (LS1, C1, C2) type is found only among diploid species belonging to the Sitopsis section and in T. turgidum, T. aestivum and T. timopheevi. Therefore the mutation(s) likely occurred in an ancient from of Sitopsis, which transmitted its cytoplasm to $T$. speltoides, $T$. aucheri, to the B genome donor of T. aestivum and T. turgidum and to the $\mathrm{G}$ genome donor of $T$. timopheevi.

If we discard the hypothesis that the same mutational event(s) occurred independantly in different cytoplasms, it can be concluded that $T$. speltoides and T. aucheri have cytoplasms that are more closely related to those of T. turgidum, $T$. aestivum and $T$. timopheevi than are the cytoplasms of any of the other diploids.

Acknowledgments We thank M. Le Guilloux, J. Blaisonneau and M.-P. Digard for technical assistance.

Note added in proof: Preliminary immunoblotting experiments (with R. Rémy and F. Ambard-Bretteville, Laboratoire de Génétique Moléculaire des Plantes, Orsay) performed with anti-beta subunit from spinach chloroplasts confirmed the suggestion that the $\mathrm{C}$ proteins are indeed two forms of the beta subunit.

\section{REFERENCES}

ANDERSON, N. L. AND ANDERSON, N. J. 1979. Microheterogeneity of serum transferrin, haptoglobin and $2 \mathrm{HS}$ glycoprotein examined by high resolution two-dimensional electrophoresis. Biochem. Biophys. Res. Commun., 88, 258265.

BAHRMAN, N. AND thiellement, H. 1987. Parental genome expression in synthetic wheats (Triticum turgidum sp. $\times T$. tauschii sp.) revealed by $2 \mathrm{D}$ electrophoresis of seedling proteins. Theor. Appl. Genet. 74, 218-223. 
BOWMAN, CM. BONNARD, G. AND DYER, TA. 1983. Chloroplast DNA variation between species of Triticum and Aegilops. Location of the variation on the chloroplast genome and its relevance to the inheritance and classification of the cytoplasm. Theor. Appl. Genet., 65, 247-252.

COLAS DES FRANCS, C. AND THIELLEMENT, H. 1985. Chromosomal localization of structural genes and regulators in wheat by 2D electrophoresis of ditelosomic lines. Theor. Appl. Genet., 71, 31-38.

DAMERVAL, C., DE VIENNE, D., ZIVY, M. AND THIELLEMENT, H. 1986. Technical improvements in two-dimensional electrophoresis increase the level of genetic variation detected in wheat seedling proteins. Electrophoresis 7, 52-54.

ELLIS, R. J. 1981. Chloroplast proteins: synthesis, transport, and assembly. Ann. Rev. Plant Physiol, 32, 111-137.

FELDMAN, M. AND KISLEV, M. 1977. Aegilops searsii, a new species of section Sitopsis (Platystachys). Isr. J. Bot., 26, 190-201.

FUKASAWA, H. 1953. Studies on restoration and substitution of nucleus in Aegilotriticum. 1. Appearance of male-sterile durum in substitution crosses. Cytologia., 18, 167-175.

GRANIER, F., THIELLEMENT, H., AMBARD-BRETTEVILLE, F. AND REMY, R. 1986. Subcellular localization of some wheat polypeptides revealed by two-dimensional electrophoresis. Electrophoresis, 7, 476-479.

HIRAI, A. AND TSUNEWAKI, K. 1981. Genetic diversity of the cytoplasm in Triticum and Aegilops. VIII. Fraction I protein of 39 cytoplasm. Genetics 99, 487-498.

HORI, T. AND TSUNEWAKI, K. 1967. Study on substitution lines of several emmer wheats having the cytoplasm of Triticum boeoticum. Seiken Ziho, 19, 55-59.

HOWE, C. J., BOWMAN, C. M., DYER, T. A. AND GRAY, J. C. 1982. Localization of wheat chloroplast genes for the Beta and Epsilon Subunits of ATP synthase. Mol. Gen. Genet., $186,525-530$.

JOHNSON, B. L. 1972. Protein electrophoretic profiles and the origin of the B genome of wheat. Proc. Nat. Acad. Sci. (U.S.A.), 69, 1398-1402.

KIHARA, H. 1951. Substitution of nucleus and its effect on genome manifestations. Cytologia, 19, 177-193.

KOFOID, K. O. AND MAAN, S. S. 1982. Agronomic and breadmaking performance of fertile alloplasmic wheats. Crop, Sci., 22, 725-729.

KUSHNiR, U. AND HALlORAN, G. M. 1981. Evidence for Aegilops sharonensis Eig. as the donor of the B genome of wheat. Genetics, 99, 495-512.

MAAN, S. S. AND LUCKEN, K. 1970. Interaction of Triticum boeoticum cytoplasm and genomes of $T$. aesticum and $T$. durum: restoration of male-fertility and plant vigor. Euphytica, 19, 498-508.
MAAN, S. S. AND LUCKEN, K. 1971. Nucleo-cytoplasmic interactions involving Aegilops cytoplasms and Triticum genomes. J. Hered., 62, 149-152.

OGIHARA, Y. AND TSUNEWAKI, K. 1982. Molecular basis of the genetic diversity of the cytoplasm in Triticum and Aegilops. I. Diversity of the chloroplast genome and its lineage revealed by the restriction pattern of ct-DNAs. Jpn. J. Genet., 57, 371-396.

REMY, R. AND AMBARD-BRETTEVILLE, F. 1983. Two dimensional analysis of chloroplast proteins from normal and cytoplasmic male sterile Brassica napus. Theor. Appl. Genet., 64, 249-253.

RILEY, R. UNRAU, J. AND CHAPMAN, V. 1958. Evidence on the origin of the $B$ genome of wheat. $J$. Hered., 49, 91-98.

SARKAR, P. AND STEBBINS, G. L. 1956. Morphological evidence concerning the origin of the B genome in wheat. Am. J. Bot., 43, 297-304.

SEARS, E. R. 1956. The B genome of Triticum. Wheat Inform. Serv., 4, 8-10.

TSUNEWAKI, K. (ed.) 1980. Genetic diversity of the cytoplasm in Triticum and Aegilops. Jpn Soc. Prom. Sci., Tokyo, 290 pp.

TSUNEWAKI, K., MUKAI, Y., ENDO, T. R., TSUJI, S. AND MURATA, M. 1976. Genetic diversity of the cytoplasm in Triticum and Aegilops. Jpn. J. Genet., 51, 175-191.

TSUNEWAKI, K. AND OGIHARA, Y. 1983. The molecular basis of the genetic diversity among cytoplasms of Triticum and Aegilops species. 2. On the origin of polyploid wheat cytoplasm as suggested by chloroplast DNA restriction fragment patterns. Genetics, 104, 155-171.

VEDEL, F., QUETIER, F., DOSBA, F. AND DOUSSINAULT, G. 1978. Study of wheat phylogeny by Eco RI analysis of chloroplastic and mitochondrial DNAs. Pl. Sci. Lett., 13, 97-102.

ZANNIS, V. I. AND BRESLOW, J. L. 1981. Human very low density apolipoprotein $\mathrm{E}$ isoprotein polymorphism is explained by genetic variation and posttranslational modification. Bio chemistry, 20, 1033-1041.

ZIVY, M., THIELLEMENT, H., DE VIENNE, D. AND HOFMANN, J. P. 1983. Study on nuclear and cytoplasmic genome expression in wheat by two-dimensional gel electrophoresis. 1. First results on 18 alloplasmic lines. Theor. Appl. Genet., 66, 1-7.

ZIVY, M., THIELLEMENT, H., DE VIENNE, D. AND HOFMANN, J. P. 1984. Study on nuclear and cytoplasmic genome expression in wheat by two-dimensional gel electrophoresis. 2. Genetic differences between two lines and two groups of cytoplasms at five developmental stages or organs. Theor. Appl. Genet., 68, 335-345. 